\section{Integration mechanisms for differenttypes of innovation: case study in innovative companies}

\author{
Fabiane Letícia Lizarelli ${ }^{1}$ \\ José Carlos de Toledo' \\ ${ }^{1}$ Federal University of São Carlos, Production Engineering \\ Department, São Carlos, Brazil \\ Dário Henrique Alliprandini² \\ ${ }^{2}$ FEI University, Department of Production \\ Engineering, São Bernardo do Campo, Brazil
}

Received on

08/24/2017

Approved on

06/13/2018

Responsible editor:

Prof. Dr. João Mauricio Gama

Boaventura

Evaluation process:

Double Blind Review

\begin{abstract}
Purpose - This paper examines the use of integration mechanisms in two innovation activities relationships: between exploitation product innovation and exploration product innovation, and between exploitation process innovation and exploration product innovation. It also identifies the benefits generated by the use of integration mechanisms.
\end{abstract}

Design/methodology/approach - A multiple case study in four companies from different sectors which are a reference in product and process innovation.

Findings - There is integration in the innovation activities relationships studied. The most used integration mechanisms in both relationships are regular collaboration, involvement for knowledge exchange (crossfunctional interface mechanisms), those related to a culture of freedom, such as the free flow and encouragement of ideas, and those related to knowledge and information exchange (connectedness mechanisms).

Originality/value - In addition to identifying that integration is possible and occurs in companies, it was possible to verify that the use of integration mechanisms enables the generation of benefits for product innovation.

Keywords - Innovation management; Product innovation; Process innovation; Integration Mechanisms.

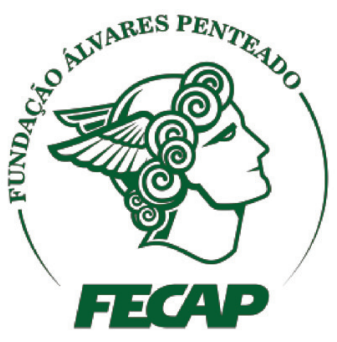

Review of Business Management

DOI: $10.7819 /$ rbgn.v0i0.3958 


\section{Introduction}

Innovation is associated with increased performance, the creation of new markets, differentiation, and competitive advantage (Blindenbach-Driessen \& Ende, 2014; Bogers \& Lhuillery, 2011; Prange \& Schlegelmilch, 2016). In addition, firms innovate to defend their existing competitive positions as well as to seek sustainable competitive advantages (Garcia \& Calantone, 2002).

Companies may adopt multiple innovation types across their corporate lifecycles, but mixing multiple types of innovation has often been considered complex, while focusing on a single type of innovation can result in decreased performance (Prange \& Schlegelmilch, 2016). In addition, different innovation types require different competencies, resources, knowledge, and investments, and imply different risk potentials (Smith \& Tushman, 2005).

It is possible to classify and differentiate innovation using dimensions such as the object of innovation and the degree of innovation. The object of innovation encompasses product innovation and process innovation (the focus of this research), marketing innovation, and organizational innovation (Organization for Economic Co-operation and Development [OECD], 2005). The degree of innovation is related to the novelty involved and this innovation has been classified as disruptive, radical, architectural, and incremental (Garcia \& Calantone, 2002).

Innovation may originate from two forces, marketing and technological, and some products may require discontinuities in both (Garcia \& Calantone, 2002). Considering technology, innovation can be, for example, incremental, architectural, or discontinuous (Christensen, 1997; Henderson \& Clark, 1990). Considering the market, innovation may focus on existing customers, new customers in defined markets, or emerging markets (Christensen, 1997; Tushman \& Smith, 2005).
Incremental technology changes to a firm's current product, targeting existing customers, is called exploitative innovation resulting in an exploitative product. Architectural or discontinuous changes in technology, targeting new customers in a defined market or emerging market, is explorative innovation (Tushman \& Smith, 2005).

Prange and Schlegelmilch (2016) developed propositions to explain the interaction between different types of innovation, considering the exploitation-exploration paradigm, which reflects the belief that companies simultaneously or sequentially adopt several types of innovation.

In the literature, exploitation refers to the refinement and extension of current knowledge in ways that are conducive to incremental innovation, while exploration refers to experimentation and the development of new knowledge leading to radical innovation and long-term success (Andriopoulos \& Lewis, 2010; Atuahene-Gima, 2005; Benner \& Tushman, 2002; March, 1991; Smith \& Tushman, 2005).

Exploitation can be defined as the incremental refinement of a firm's existing products aimed at improving existing productmarket domains, and exploration can be seen as the development of new products aimed at new product-market domains (Piao \& Zajac, 2016). Exploration leads to completely new innovations and exploitation preserves existing innovations (Prange \& Schlegelmilch, 2016).

Early research observed the explorationexploitation paradigm and viewed the innovation types as being exclusive; however a few studies have started to consider the simultaneousness of exploitative and explorative innovation (He \& Wong, 2004; Prange \& Schlegelmilch, 2016; Rothaermel \& Deeds, 2004). Successful exploration creates demand to exploit newly discovered opportunities. Valuable knowledge and skills are acquired through exploration, and the firm then turns to exploitation activities (Rothaermel \& Deeds, 2004). Piao and Zajac (2016) identified two types of exploitation: 
repetitive exploitation (the repetition of existing designs for existing products) and incremental exploitation (the creation of new designs for existing products) and they recognized that these two types of exploitation have different effects on exploration.

We proposed to use the explorationexploitation concept for product and process innovations. Exploitative innovation is defined, in this research, as the set of activities to incrementally refine a firm's existing processes or existing products that focus on existing productmarket domains, while explorative innovation is the development of new processes or products aimed at entering new product-market domains.

Considering that adopting multiple types of innovation is beneficial to the organization's performance (Prange $\&$ Schlegelmilch, 2016) and observing that there may be simultaneity between exploitation and exploration innovation ( $\mathrm{He} \&$ Wong, 2004; Rothaermel \& Deeds, 2004), one question to be answered is whether simultaneity can enable interaction and collaboration between exploration and exploitation innovation activities, which can be identified by the presence of integration mechanisms (Jansen, Tempelaar, Bosch, \& Volberda, 2009). Recent developments in the literature have suggested an approach which focuses on the integration of exploration and exploitation activities (Colombo, Doganova, Piva, D’Adda, \& Mustar, 2014) and despite the benefits that may result, the research on explicit integration mechanisms is still scarce (Gassmann, Widenmayer, \& Zeschky, 2012).

Integration is explained primarily in organizational learning and innovation management literature (Martini, Laugen, Gastaldi, \& Corso, 2013), and emphasizes the interdependence of opposing constructs by enabling the coordination and sharing of divergent knowledge (Chang \& Hughes, 2012), through social, cognitive, and organizational integration mechanisms (Jansen et al., 2009; Martini et al., 2013). While integration is necessary to successfully obtain a balance between innovative activities (Gassmann et al., 2012; Jansen et al., 2009), there are few studies on integration mechanisms related to exploration and exploitation (Gassmann et al., 2012; Jansen et al., 2009; Wang \& Rafiq, 2014).

Integration considers the exploitation and exploration tensions to be intertwined and synergistically connected (Andriopoulos \& Lewis; 2009), and it supports improved coordination of knowledge sharing and connection between individuals (Chang \& Hughes, 2012). Organizational integration mechanisms are associated with knowledge combination in two dual structures: formal cross-functional interfaces, and informal social relations or connectedness (Jansen et al., 2009). While previous research has emphasized the tensions engendered by the combination of exploration and exploitation, the integration of these two types of activities also can generate synergies (Colombo et al., 2014).

Considering that companies adopt multiple types of innovation, the purpose of this research is to identify if companies use integration mechanisms between exploitative and explorative innovation to foster interaction between these activities, as well as to identify the benefits for the product development process. The research observed the use of integration mechanisms between: (i) exploitative product innovation and explorative product innovation, and (ii) exploitative process innovation and explorative product innovation. We adopted the multiple case study method in four companies from different sectors which are a reference in product and process innovation.

The research contributes to the literature related to exploration-exploitation innovation concepts by showing that in addition to the need for the co-existence and balancing of exploitative and explorative innovation these activities can be integrated and may foster better results for product innovation (Chen \& Kannan-Narasimhan, 2014; Colombo et al., 2014; Gassmann et al., 2012; Raisch, Birkinshaw, Probst, \& Tushman, 2009). The studies on integration are scarce and there are 
no studies that deepen the analysis of mechanisms for the integration of exploitative and explorative innovation activities. Another contribution is that the study addresses integration by separating product and process activities, enabling a better understanding of how integration mechanisms can occur, and the benefits generated.

In relation to managerial implications, by identifying integration mechanisms at team and individual levels and their impact on product innovation, companies can organize themselves in a way that structures and facilitates the occurrence of the most impacting mechanisms and rethink the exploitation-exploration paradigm using a collaborative vision.

The paper has four additional sections: the literature review; the method, which presents the research stages; the field research and data analysis results; and the conclusions.

\section{Literature Review}

\section{I Exploitation and exploration}

The concept of exploration and exploitation is related to ambidextrous companies. The first time the term ambidextrous was used was in a paper by Duncan (1976). In the author's ambidextrous model there are two stages related to innovation adoption: initiation and implementation. The first one is more related to organic characteristics - high structural complexity and less formalization and centralization - while mechanistic characteristics facilitate implementation - low structural complexity and a high level of formalization and centralization. March (1991) extends Duncan's (1976) studies (Martins, Rosseto, Lima, \& Pereira, 2014) and is the main influencer of the research on organizational ambidexterity and the most mentioned in research on the subject from 1993 to 2010 (Silveira-Martins \& Rossetto, 2014).

To expand the studies of Duncan (1976), March (1991) proposes the terms exploitation and exploration, which were defined by Duncan (1976) as implementation and initiation, respectively (Martins et al., 2014). Exploration is related to research, risk taking, experimentation, and innovation, while exploitation is related to refinement, efficiency, execution, and implementation (March, 1991).

Considering an innovation context, exploitation is associated with incremental innovations, which enhance knowledge, skills, processes, and existing structures; while exploration is associated with radical innovations obtained through experimentation, inventions, discoveries, and new capabilities (Benner \& Tushman, 2002; Smith \& Tushman, 2005).

March (1991) asserts that exploration and exploitation are essential for organizations, but they compete for resources, and this generates doubts about investing more in exploration or exploitation. The ability to balance the organization's exploration and exploitation generates a company's ability to be ambidextrous (March, 1991). However, they contain inherent tensions that need to be managed (Tushman \& O’Reilly, 1996).

The tension generated by organizational ambidexterity involves balancing exploitation and exploration for success in the short term while at the same time ensuring success in the future (Gibson \& Birkinshaw, 2004; O’Reilly \& Tushman, 2004). Therefore, some authors have argued that successful organizations are those that are able to balance exploitation and exploration (Benner \& Tushman, 2003; Smith \& Tushman, 2005; Tushman \& O’Reilly, 1996).

However, there is a lack of consensus on the best method and concept of ambidexterity, since the balance between exploitation and exploitation does not seem to be unanimous among researchers (Silveira-Martins \& Rossetto, 2014). Martins-Silveira, Rossetto, and Añañas (2014) argue that not only the ambidextrous strategies of equilibrium between exploitation and exploration, but also exploitation and exploitation actions, are positively related to the performance of organizations. The greater the investment in these practices (ambidexterity, exploration, or exploitation), the greater the performance of the 
companies will be (Martins-Silveira et al., 2014).

The idea of exploration and exploitation is complex and it is difficult to elaborate a definition in few words (Popadiuk \& Bidu, 2016). The exploration-exploitation concepts are applied to several organizational phenomena (Sirén, Kohtamäki, \& Kuckertz, 2012). Exploration and exploitation may be seen as different strategic views. The exploration strategy aims to create new business opportunities through new products and services that are innovative to the firm, looking for novel technological ideas (Moreira, Torkomian, \& Soares, 2016; Sirén et al., 2012). In contrast, the goal of exploitation strategies is to exploit a firm's current competitive advantage by managing the firm's existing resources and capabilities to improve the quality and reliability of current products and services to keep current customers satisfied (Sirén et al., 2012).

The exploration-exploitation concept may also be observed from the competence point of view. Competence exploitation reveals that a firm invests its resources in the reinforcement of existing knowledge, skills, processes, and structures, and competence exploration reflects an effort to acquire entirely new knowledge, skills, and processes (Atuahene-Gima, 2005; Molina-Castillo, Jimenez-Jimenez, \& MunueraAleman, 2011; Yang \& Li, 2011). Previous studies indicate that the combination of exploitation and exploration of knowledge is the ideal strategy for innovation as the organization will access new technologies through the exploration of new knowledge and refine the dominant technology through the exploitation of primary knowledge (Gonzalez \& Melo, 2018).

Considering product innovation competences, few companies are able to exploit their existing competences, while at the same time renewing and replacing them (AtuaheneGima, 2005). Exploitative innovation is aimed at improving existing product-market domains and involves investing resources to refine and extend existing product innovation knowledge (Atuahene-Gima, 2005; Benner \& Tushman,
2002; Derbyshire, 2014; Güttel, Konlechner, \& Trede, 2015; Huang, Ma, \& Le, 2015; MolinaCastillo et al., 2011; Smith \& Tushman, 2005; Soosay \& Hyland, 2008). It represents the refinement of existing routines to develop a new product (O'Cass, Heirati, \& Ngo, 2014).

Exploitation minimizes the risks and failures in the innovation process of new products, preferably using existing competences that is related, for example, to process improvement initiatives to provide new product quality (Molina-Castillo et al., 2011). The returns from exploitation are usually positive and predictable (He \& Wong, 2004) and product exploitation emphasizes increasing returns from existing product capabilities (Voss \& Voss, 2012).

An exploratory innovation is a technological innovation aimed at entering new product-market domains (Molina-Castillo et al., 2011) and it is associated with radical innovations, risk, and experimentation that offer differentiated advantages to customers (Jansen, Bosch, \& Volberda, 2006). It refers to the generation of new routines to develop new products (O'Cass et al., 2014) and to the development of new knowledge (Atuahene-Gima, 2005; Benner \& Tushman, 2002; Derbyshire, 2014; Güttel et al., 2015; Smith \& Tushman, 2005), and product exploration emphasizes developing new products, technologies, and product capabilities (Voss \& Voss, 2012).

Dedication to multiple types of innovation has often been considered a complex problem, but dedication to a single type of innovation can be associated with decreased performance (Prange $\&$ Schlegelmilch, 2016). Smith and Tushman (2005) proposed a solution to the low-performance of isolated innovation strategies: innovation streams.

An innovation stream refers to the portfolio of products simultaneously existing and managed by an organization and the products are classified considering its technology and target markets (Smith \& Tushman, 2005). An innovation stream is composed of continued incremental innovation in the existent products, as well as at 
least one nonincremental innovation (Smith \& Tushman, 2005). Tushman and O’Reilly (1997) state that leadership teams may be able to obtain innovation streams because existing products and services create new ones. The authors point out that companies can compete in mature markets focusing on quality and cost and in new markets focusing on speed and adaptability.

Exploitative innovation activities considering process innovation (hereafter exploitative process innovation) refer to the ability to apply minor or incremental improvements or investments to goods in an existing production process. Explorative innovation activities refer to the ability to create and adopt an entirely new production process which is new or radically changed compared to the company's existing production process (Bauer \& Leker, 2013; Lin \& McDonough, 2011).

Exploitative innovation activities considering product innovation (hereafter exploitative product innovation) are related to the improvements and refinements of existing products and incremental technology changes to the firm's current products targeting existing markets, resulting in exploitative products (Bauer \& Leker, 2013; Smith \& Tushman, 2005; Wang \& Rafiq, 2014). Explorative innovation activities considering product innovation (explorative product innovation) refer to discontinuous changes in technology focusing on new customers in a defined market or emerging market, requiring a significant amount of research, risk, and experimentation (Bauer \& Leker, 2013; Wang \& Rafiq, 2014).

To develop new products, a firm should have multiple projects to engage in distinct types of learning activities, such as exploration and exploitation (Gupta, Smith, \& Shalley, 2006). The New Product Development (NPD) process is a multidimensional phenomenon, in which the focus may be on improving existing products (incremental NPD processes) through conducting exploitative activities such as optimization, standardization, and refinement, or the focus may be on generating new products (radical NPD processes) through explorative activities such as research, experimenting, and prototyping (Benner \& Tushman, 2003; Visser et al., 2010).

Exploration is stimulated by the desire to discover something new, while exploitation is based on the existence of an exploitable set of resources, capabilities, or knowledge controlled by the firm (Rothaermel \& Deeds, 2004). Firms engage in both activities simultaneously because they manage several concurrent projects at different stages in the product development process (Rothaermel \& Deeds, 2004).

Knowledge and skills are acquired through exploration, and the firm then turns to exploitation activities, so exploitation activities depend upon prior exploration (Rothaermel \& Deeds, 2004). However, other authors propose that exploitation precedes exploration as it is necessary to ensure current viability and it is believed that simultaneousness is possible (Prange \& Schlegelmilch, 2016). Lakemond and Detterfelt (2013) explored how firms can reinforce new exploratory ideas for existing products, creating opportunities for counterbalancing exploitative approaches by building exploratory skills.

Piao and Zajac (2016) identified different types of exploitation related to product innovation: incremental and repetitive exploitation. Incremental exploitation creates distinctively better products or services, while repetitive exploitation reduces cost and improves efficiency, typically involving little or no change. Incremental exploitation can be a bridge between firms' existing activities and their new products. When a firm practices incremental exploitation, it enables the generation of other incremental searches, and can generate discoveries emerging from constant interactions between the search efforts. Therefore, exploitative product innovation and explorative product innovation may be related.

Explorative product innovation and exploitative process innovation can occur independently, however, and they have the 
potential to benefit from each other by triggering innovations in processes, products, and technologies and creating an innovation stream (Bauer \& Leker, 2013; Boland, Lyytinen, \& Yoo, 2007; Zairi, 1995). Therefore, exploitative process innovation and explorative product innovation may be related, and for this reason an investigation regarding the use of integration mechanisms can help elucidate the issue.

\subsection{Integration mechanisms related to exploitation and exploration}

Adler, Goldoftas, and Levine (1999) and Raisch et al. (2009) state that differentiation and integration are alternative or complementary ways to balance exploitation and exploration. Integrative techniques emphasize efforts to promote synergies, while differentiation tactics are used to separate tensions and focus on resources and actions (Andriopoulos \& Lewis, 2009).

Considering that integration plays a crucial role in a firm's ability to pursue exploratory and exploitative innovation concurrently, the organization must analyze how to enable integration (Gibson \& Birkinshaw, 2004; He \& Wong, 2004; Tushman \& O’Reilly, 1996), the processes by which these units are integrated in order to add value (O'Reilly \& Tushman, 2008).

One of the ways to develop and balance exploitation and exploration is through structural separation, which is a form of spatial separation, in which exploitation and exploration occur simultaneously, but are located in different organizational units. Certain departments will have an organic configuration that is smaller, more decentralized, and flexible, thus facilitating exploration, while other units will be more mechanical to focus on exploitation activities (Benner \& Tushman, 2003; He \& Wong, 2004; Turner \& Lee-Kelley, 2013; Tushman \& O'Reilly, 1996).

It is suggested by several authors that when there is structural separation integration must occur at the top management level, so that the units can cooperate in relation to critical resources, such as financial resources, knowledge, skills, and customers (Gibson \& Birkinshaw, 2004; He \& Wong, 2004; O’Reilly \& Tushman, 2004; Tushman \& O’Reilly, 1996).

However, according to Raisch et al. (2009), differentiation refers to the separation of exploration and exploitation activities in different organizational units (structural separation) and integration refers to mechanisms that allow organizations to address ambidextrous activities in the same organizational unit. Gibson and Birkinshaw (2004) have also highlighted that in the same business units there can be a context that induces their individual members to engage in exploration and exploitation.

This is called contextual ambidexterity and it uses more behavioral and social means to foster an organizational context that encourages ambidextrous efforts in the whole organization (Birkinshaw \& Gibson, 2004; Andriopoulos \& Lewis, 2009). An ambidextrous context should encourage individuals to make their own judgments on how to better divide their time between conflicting demands (Gibson \& Birkinshaw, 2004).

At the organizational level, contextual ambidexterity can be defined as a collective orientation for employees through the simultaneous pursuit of alignment and adaptation (Birkinshaw \& Gibson, 2004). At the individual level, it is related to more flexible systems and structures, allowing collaborators to use their own judgment to divide their time between activities aimed at alignment or at flexibility (Birkinshaw \& Gibson, 2004; Raisch et al. 2009).

The integration that is the focus of this study is integration at the level of teams or individuals that participate in activities of exploitative innovation or explorative innovation.

There has been no discussion on the potential synergies between exploitation and exploration activities and integration can create unique synergies through coordination benefits (Colombo et al., 2014). Many researchers have identified the need to integrate exploration and 
exploitation but by making a trade-off between the two perspectives (Palm, Lilja, \& Wiklund, 2016).

Increasing the frequency of interactions between exploration and exploitation activities and enriching available communication channels can be achieved by alliances that delete organizational boundaries (Colombo et al., 2014). Integration can easily be achieved when teams are co-located, so inter-individual communication overflows formal channels and takes place in spontaneous day-today interactions, which enables understanding with the respective cognitive schemes and thought worlds (Colombo et al., 2014).

Gassmann et al. (2012) observed practices that range from a conjoint definition of goals and involvement in decision making to cooperative development. A reference framework is a necessary premise for integration and is created with wide background knowledge, a common language to facilitate communication, and continuous socialization and interaction. Interaction among departments or business units may create bridges that allow for knowledge transfer, continuous job rotation, and common training, among others benefits (Güttel et al., 2015).

The organizational culture of a shared vision, or multiple individual knowledge combined with skills and abilities that promote creativity, is the foundation of integrating explorative and exploitative activities (Wang \& Rafiq, 2014). Authors argue that balancing exploration and exploitation requires the development of integrative capabilities because the locus of integration is decentralized (Benner \& Tushman, 2015; Wang \& Rafiq, 2014).

Integration should be based on informal communication and knowledge sharing. In this context, companies can refine technologies, existing products, and functions to feed exploitation (Chang \& Hughes, 2012; Jansen et al., 2006). Exploitative and explorative innovation activities are dependent on knowledge and learning, and the dynamic of this knowledge and learning makes the integration possible, as well as having an impact on innovation performance ( $\mathrm{Su}$, Li, Yang, \& Li, 2011).

Organizational integration mechanisms should support knowledge exchange and the combination of differentiated units, skills, and experience (Jansen et al., 2009). Other studies have emphasized the need for companies to use formal and informal integration mechanisms (Westerman, McFarlan, \& Iansiti, 2006).

Jansen et al. (2009) considers two types of organizational integration mechanisms that have been associated with knowledge combination and integration in dual structures: formal crossfunctional interfaces and informal social relations or connectedness. Connectedness relates to the social network that can be established by an organization to enable knowledge exchange. Connectedness affects the ability and motivation to integrate and recombine differentiated knowledge sources in different units (Jansen et al., 2009). Formal cross-functional interface mechanisms are related to mechanisms such as liaison personnel, job rotation, cross-functional teams, and all mechanisms that enable deeper knowledge flows across exploratory and exploitative units (Jansen et al., 2009). These two types of mechanisms are observed in field research. Table 1 shows the main mechanisms and authors related. 
Table 1

Main integration mechanisms found in literature review

\begin{tabular}{|c|c|c|}
\hline \multicolumn{2}{|c|}{ Mechanisms (M) } & \multirow{2}{*}{$\begin{array}{l}\text { Authors } \\
\text { Jansen et al. (2009); Güttel et al. (2015) }\end{array}$} \\
\hline \multirow{3}{*}{ 它 } & Use of regular job rotation & \\
\hline & $\begin{array}{l}\text { Use of regular collaboration between units and } \\
\text { liaison persons }\end{array}$ & Jansen et al. (2009); Gassmann et al. (2012) \\
\hline & $\begin{array}{l}\text { Use of cross-functional teams for the exchange of } \\
\text { knowledge between units }\end{array}$ & $\begin{array}{l}\text { Jansen et al. (2009); Colombo et al. (2014); Xu, Cui, Qualls, \& Zhang } \\
\text { (2017) }\end{array}$ \\
\hline \multirow{4}{*}{ 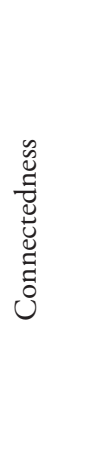 } & $\begin{array}{l}\text { Use of regular information and knowledge } \\
\text { exchange between units/projects }\end{array}$ & $\begin{array}{l}\text { Jansen et al. (2006); Jansen et al. (2009); Su et al., (2011); Gassmann et al. } \\
\text { (2012); Colombo et al. (2014); Chang \& Hughes (2014); Wang \& Rafiq } \\
\text { (2014); Güttel et al. (2015); Xu et al. (2017) }\end{array}$ \\
\hline & Use of regular goals and objectives sharing & $\begin{array}{l}\text { Jayawarna \& Holt (2009); Gassmann et al. (2012); Chen \& Kannan- } \\
\text { Narasimhan (2014); Xu et al. (2017) }\end{array}$ \\
\hline & $\begin{array}{l}\text { Use of informal talks and regular meetings } \\
\text { for socialization and exchanging information } \\
\text { between people from units }\end{array}$ & $\begin{array}{l}\text { Westerman et al. (2006); Jansen et al. (2009); Jayawarna \& Holt (2009); } \\
\text { Chen \& Kannan-Narasimhan (2014); Colombo et al. (2014); Gütttel } \\
\text { et al. (2015) }\end{array}$ \\
\hline & $\begin{array}{l}\text { Consolidation of a culture of freedom for people } \\
\text { to feel free to get in touch and share knowledge } \\
\text { as needed with people from other units/ projects }\end{array}$ & $\begin{array}{l}\text { Jansen et al. (2009); Colombo et al. (2014); Wang \& Rafiq (2014); Gütttel } \\
\text { et al. (2015); Xu et al., (2017) }\end{array}$ \\
\hline
\end{tabular}

Table 1 is the result of a systematic literature review conducted in the Web of Science database, for a better understanding of the integration mechanisms that are used in the context of exploitative and explorative innovation. The search used the following string: (( ("explorative innovation”) OR("exploitative innovation") OR( “exploratory innovation”) OR((“exploitation”)AND(“exploration”)) AND(innovation))AND(integration)), searching in all available periods (1945- February 2018). The search returned 132 items, and we chose to read the journal papers (109 papers). All the titles and abstracts were read and 32 papers were selected after reading them all. The result is shown in Table 1 . The reduced number of papers shows that there is still a need to study the subject.

In addition, despite the identification of articles that investigate integration in the context of exploitation-exploitation, there are no articles that relate explorative product innovation and exploitative process innovation or exploitative product innovation.

\section{Method}

The methodological procedure adopted was a multiple case study, which is indicated for new areas of research, exploratory studies, and the creation of hypotheses and theories (Eisenhardt, 1989; Yin, 1994). Multiple cases were selected to increase the robustness of the results: the increase in external validity reduces bias, observer influences, and the risks of a false conclusion generated by a single event (Voss, Tsikriktsis, \& Frohlich, 2002).

The research subject was the individual's perspective of the organization. The researchers tried to interview individuals who exercise functions and understand both the dynamics of exploration and exploitation innovative activities and the possible integration between them. We gathered data during two rounds of interviews and reports through semi-structured interviews, which enabled us to further refine the information.

We carried out the investigation of the integration mechanisms in two relationships: (i) exploitative activities of product innovation and explorative activities of product innovation, and (ii) exploitative activities of process innovation and explorative activities of product innovation (Figure 1). 


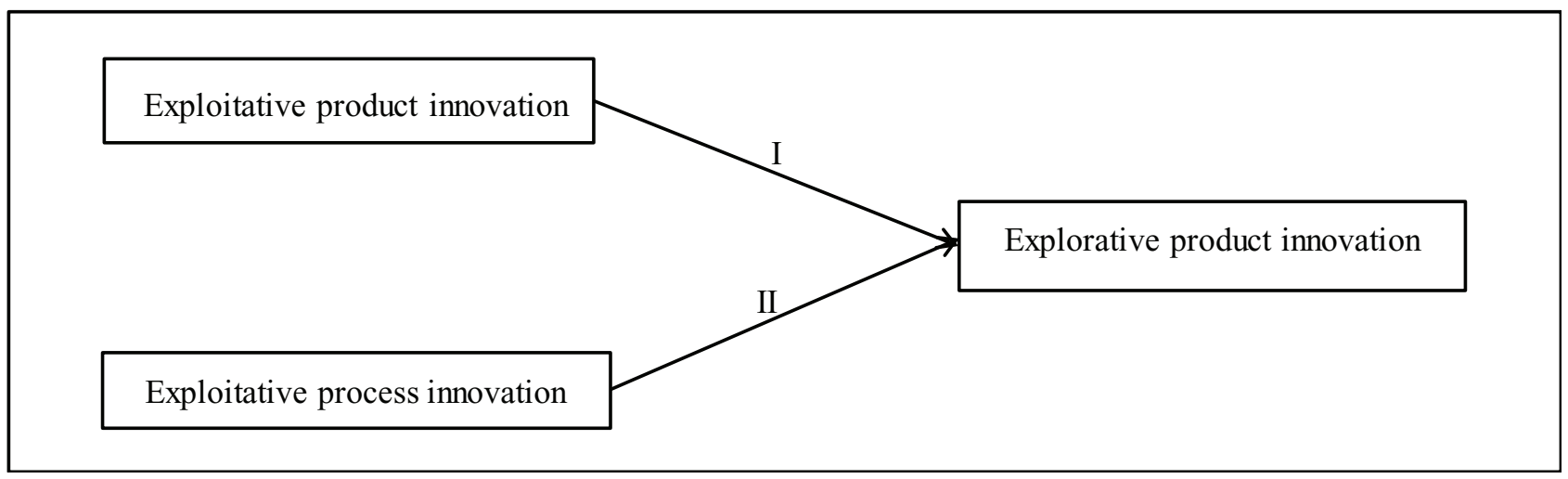

Figure 1. Investigated relationships

The research development steps (Figure 2) involved: 1) identifying companies and people to interview; 2) preliminary interviews for questionnaire validation and to identify other specific integration mechanisms for each relationship, as well as the benefits derived from the use of each mechanism; 3) final interviews concerning the interviewee's perspective of the degree of presence (non-existent, low, medium, or high) of the integration mechanisms identified in the literature and in preliminary interviews, for the company in general and specifically for each relationship; 4) the compilation of interviewee viewpoints about the presence of mechanisms and benefits; and 5) data analysis and conclusions.

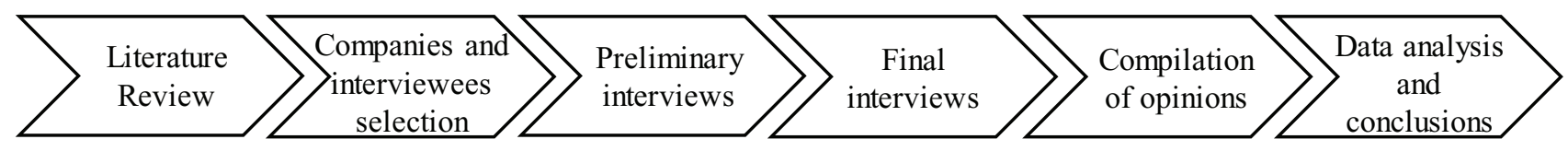

Figure 2. Research Steps

To select companies in which it would be possible to observe exploitation and exploration activities in products and processes, we consulted information about the introduction of new products to the market, the introduction of incremental and radical innovations, and the number of patents (Instituto Nacional da Propriedade Industrial [INPI], 2015). We also identified companies that have been practicing activities related to process innovation and improvement.

A preliminary questionnaire based on O'Cass et al. (2014), Voss and Voss (2012), and Lin and McDonough (2011) was sent to guarantee the existence of exploitative and explorative innovation activities. We initially contacted eight companies to verify if the requirements for the research were fulfilled, and four companies met the requirements and agreed to participate.

The selected companies belong to different sectors of activity, allowing for broader research on the mechanisms of integration in different contexts. If only one sector was investigated, the presence or absence of integration mechanisms could be conditioned to the sector. There was no size restriction, yet only large companies met the criteria.

After the cases were selected, we determined the research methods and techniques for data collection and data analysis. We aimed to employ multiple sources of evidence: interviews, document analysis, and observation were usually considered (Yin, 1994).

We conducted the research in two stages, which enabled data collection and data analysis 
to be alternately carried out. The first stage of the field research consisted of preliminary interviews, questionnaire testing, and instrument refinement. The interviews were used to evaluate the questionnaire and to refine the specific integration mechanisms and benefits that were not found in the literature but were identified in the preliminary interviews. Stage 1 occurred in three companies (A, B, and $\mathrm{C}$ ), where seven interviews were conducted, three in company A (R\&D Lab Manager, R\&D Technical Expert, Manufacturing Engineer), two in company B (Senior Manager of Product Development, Process Engineer), and two in company C (Innovation Project Manager, Coordinator of Manufacturing Processes) for the validation of the questionnaire and refinement. In stage 2, new interviews were conducted with the interviewees from stage 1 using the refined questionnaire and new interviewees were added to obtain more accurate data and information.

First, we contacted the innovation product manager or similar position, who assisted in conducting the other interviews. We also interviewed the person in charge of the company for activities of exploitative innovation of productive processes, as well as the person responsible for activities of exploitative innovation of products and the person responsible for managing product development projects. This person was chosen for their experience and the number of projects developed, being the leader with the highest number of project leadership roles in the last three years.

The positions held were not the same in all the companies interviewed, and some people had more than one function. Generally, the positions were innovation project leader, innovation manager, and people involved with product and process innovation and improvement. However, including different points of view was crucial to the outcome of the work. The interviewees in stage 1 were interviewed more than once for follow-up questions and validation. They were interviewed again in stage 2 , after refining the questionnaire. In total, 29 interviews were conducted and emails were exchanged and phone conversations held after the interviews for additional information and clearing up doubts.

In stage 1, we accompanied the activities of explorative product innovation, more specifically two new product development projects in each of the companies, and we carried out passive observation in order to see how the mechanisms are used for integration. We also observed documents and information contained in project monitoring platforms, where meetings and information exchange between people related to the explorative product innovation and exploitative process and product innovation activities could be identified. The interviews, passive observation, and observation of documents were determinant for information triangulation and bias reduction.

With the information obtained in stage 1 , it was possible to generate more in-depth interviews with knowledge in the subject, which was the focus of stage 2 .

Table 2 shows the questions related to each mechanism or benefit, some comments, and the authors reference. The abbreviations shown in table 2 - MCFI and MC - mean, respectively, mechanisms of cross-functional interfaces and mechanisms of connectedness, as established by Jensen et al. (2009). After stage 1, some questions were modified, as it is possible to observe in the table. 
Table 2

Questionnaire, modifications, and authors

\begin{tabular}{|c|c|c|}
\hline Characteristics & Question & Comments/Authors \\
\hline Structure & $\begin{array}{l}\text { Is there a structural separation between the units of exploitative } \\
\text { innovation and explorative innovation? } \\
\text { In which unit do the activities of exploitative process innovation } \\
\text { occur? } \\
\text { In which unit do the activities of exploitative product innovation } \\
\text { occur? } \\
\text { In which unit do the activities of explorative product innovation } \\
\text { occur? }\end{array}$ & $\begin{array}{l}\text { Tushman \& O’Reilly (1996); Benner \& } \\
\text { Tushman (2003); He \& Wong (2004) }\end{array}$ \\
\hline Activities & $\begin{array}{l}\text { What activities are engaging in explorative product innovation } \\
\text { for the company? } \\
\text { What activities are engaging in exploitative process innovation for } \\
\text { the company? } \\
\text { What activities are engaging in exploitative product innovation } \\
\text { for the company? }\end{array}$ & $\begin{array}{l}\text { Tushman \& Smith (2005); Lin \& McDonough } \\
\text { (2011); Bauer \& Leker (2013); Wang \& Rafiq, } \\
\text { (2014); Piao and Zajac (2016) }\end{array}$ \\
\hline \multirow{9}{*}{$\begin{array}{l}\text { Integration } \\
\text { mechanisms } \\
\text { between } \\
\text { exploitative } \\
\text { product } \\
\text { innovation and } \\
\text { explorative } \\
\text { product } \\
\text { innovation }\end{array}$} & $\begin{array}{l}\text { Is there integration between exploitative product innovation and } \\
\text { explorative product innovation? How does this integration occur } \\
\text { at the individual level? }\end{array}$ & Gassmann et al. (2012); Colombo et al. (2014) \\
\hline & $\begin{array}{l}\text { MCFI1: Is there use of regular job rotation between exploitative } \\
\text { and explorative product innovation activities/units? How is the } \\
\text { use of this mechanism guaranteed? * How intensely does the } \\
\text { company use this mechanism? * }\end{array}$ & Jansen et al. (2009); Güttel et al. (2015) \\
\hline & $\begin{array}{l}\text { After stage 1: MCFI2: Is there involvement of people related to } \\
\text { the exploitative product innovation activities in the explorative } \\
\text { product innovation activities for knowledge exchange? }\end{array}$ & Mechanisms added by respondents in stage 1 \\
\hline & $\begin{array}{l}\text { MCFI3: Is there use of regular collaboration between people } \\
\text { from the exploitative and explorative product innovation } \\
\text { activities/units? }\end{array}$ & Jansen et al. (2009); Gassmann et al. (2012) \\
\hline & $\begin{array}{l}\text { MCFI4: Is there use of cross-functional teams with connections } \\
\text { between explorative product innovation activities/units and } \\
\text { exploitative product innovation activities/units? }\end{array}$ & $\begin{array}{l}\text { Jansen et al. (2009); Colombo et al. (2014); Xu } \\
\text { et al. (2017) }\end{array}$ \\
\hline & $\begin{array}{l}\text { MC1: Is there regular information exchange between exploitative } \\
\text { and explorative product innovation activities/units? }\end{array}$ & $\begin{array}{l}\text { Jansen et al. (2006); Jansen et al. (2009); Su et } \\
\text { al., (2011); Gassmann et al. (2012); Colombo } \\
\text { et al. (2014); Chang \& Hughes (2014); Wang } \\
\text { \& Rafiq (2014); Güttel et al. (2015); Xu et al. } \\
\text { (2017) }\end{array}$ \\
\hline & $\begin{array}{l}\text { Before stage } 1 \text { - Is there use of regular goals and objectives } \\
\text { sharing? } \\
\text { After stage } 1 \text { - MC2: Are the goals of new product innovation for } \\
\text { new customers used for focusing exploitative product innovation } \\
\text { activities? }\end{array}$ & $\begin{array}{l}\text { Mechanism changed due to the responses in } \\
\text { stage } 1 \\
\text { Jayawarna \& Holt (2009); Gassmann et al. } \\
\text { (2012); Chen \& Kannan-Narasimhan (2014); } \\
\text { Xu et al. (2017) }\end{array}$ \\
\hline & $\begin{array}{l}\text { Before stage 1: Is there use of regular information exchange } \\
\text { between exploitative and explorative product innovation } \\
\text { activities/units? } \\
\text { After stage 1:MC3: Is knowledge of radical/new product } \\
\text { innovation for new customers incorporated into reports and } \\
\text { databases, among others, for later access for exploitative product } \\
\text { innovation activities? }\end{array}$ & $\begin{array}{l}\text { Mechanism changed due to the responses in } \\
\text { stage } 1 \\
\text { Jansen et al. (2006); Jansen et al. (2009); Su et } \\
\text { al., (2011); Gassmann et al. (2012); Colombo } \\
\text { et al. (2014); Chang \& Hughes (2014); Wang } \\
\text { \& Rafiq (2014); Güttel et al. (2015); Xu et al. } \\
\text { (2017) }\end{array}$ \\
\hline & $\begin{array}{l}\text { Before stage 1: Is there use of regular information exchange } \\
\text { between exploitative and explorative product innovation } \\
\text { activities/units? } \\
\text { After stage 1: MC4: Is knowledge of incremental product } \\
\text { innovations incorporated into reports and databases, among } \\
\text { others, for later access for explorative product innovation } \\
\text { activities? }\end{array}$ & $\begin{array}{l}\text { Mechanism changed due to the responses in } \\
\text { stage } 1 \text { in stage } 1 \\
\text { Jansen et al. (2006); Jansen et al. (2009); Su et } \\
\text { al., (2011); Gassmann et al. (2012); Colombo } \\
\text { et al. (2014); Chang \& Hughes (2014); Wang } \\
\text { \& Rafiq (2014); Güttel et al. (2015); Xu et al. } \\
\text { (2017) }\end{array}$ \\
\hline
\end{tabular}




\begin{tabular}{|c|c|c|}
\hline Characteristics & Question & Comments/Authors \\
\hline & $\begin{array}{l}\text { MC5: Are there communication and meetings (including } \\
\text { forums and committees) between people from exploitative and } \\
\text { explorative product innovation activities/units? }\end{array}$ & $\begin{array}{l}\text { Westerman et al. (2006); Jayawarna \& Holt } \\
\text { (2009); Gütttel et al. (2015) }\end{array}$ \\
\hline & $\begin{array}{l}\text { Before stage 1: Is there consolidation of a culture of freedom for } \\
\text { people to feel free to get in touch and share knowledge as needed } \\
\text { with people from other units/ projects? } \\
\text { After stage 1: MC6: Is there the free flow of ideas and } \\
\text { information from exploitative product innovation activities/units } \\
\text { to explorative product innovation activities/units? }\end{array}$ & $\begin{array}{l}\text { Mechanism changed due to the responses in } \\
\text { stage } 1 \text { in stage } 1 \\
\text { Jansen et al. (2009); Colombo et al. (2014); } \\
\text { Wang \&Rafiq (2014); Gütttel et al. (2015); Xu } \\
\text { et al. (2017) }\end{array}$ \\
\hline & $\begin{array}{l}\text { Before stage 1: Is there consolidation of a culture of freedom for } \\
\text { people to feel free to get in touch and share knowledge as needed } \\
\text { with people from other units/ projects? } \\
\text { After stage 1: MC7: Is there the encouragement of ideas and } \\
\text { contributions from exploitative product innovation activities/ } \\
\text { units to explorative product innovation activities/units }\end{array}$ & $\begin{array}{l}\text { Mechanism changed due to the responses in } \\
\text { stage } 1 \text { in stage } 1 \\
\text { Jansen et al. (2009); Colombo et al. (2014); } \\
\text { Wang \& Rafiq (2014); Gütttel et al. (2015); Xu } \\
\text { et al. (2017) }\end{array}$ \\
\hline $\begin{array}{l}\text { Benefits of the } \\
\text { integration } \\
\text { between } \\
\text { exploitative } \\
\text { product } \\
\text { innovation and } \\
\text { explorative } \\
\text { product } \\
\text { innovation }\end{array}$ & $\begin{array}{l}\text { Before stage 1: What are the benefits of the integration between } \\
\text { exploitative product innovation and explorative product } \\
\text { innovation? What are the mechanisms that most help in } \\
\text { achieving these benefits? } \\
\text { After stage 1: B1: Is there the incorporation of features in existing } \\
\text { products for improvements which were developed in explorative } \\
\text { product innovation? } \\
\text { After stage 1: B2: Is there the development of radical/new } \\
\text { product innovation for new customers with the incorporation } \\
\text { of improvements proposed by the market or internally in } \\
\text { exploitative product innovation activities? } \\
\text { After stage 1: B3: Is there a reduction in the development time of } \\
\text { radical/new products for new customers? } \\
\text { What are the mechanisms that most help in achieving these } \\
\text { benefits? }\end{array}$ & $\begin{array}{l}\text { Benefits were changed due to the responses in } \\
\text { stage } 1 \text { in stage } 1\end{array}$ \\
\hline \multirow{7}{*}{$\begin{array}{l}\text { Integration } \\
\text { mechanisms } \\
\text { between } \\
\text { exploitative } \\
\text { process } \\
\text { innovation and } \\
\text { explorative } \\
\text { product } \\
\text { innovation }\end{array}$} & $\begin{array}{l}\text { Is there integration between exploitative process innovation and } \\
\text { explorative product innovation? How does this integration occur } \\
\text { at the individual level? }\end{array}$ & Gassmann et al. (2012); Colombo et al. (2014) \\
\hline & $\begin{array}{l}\text { MCFI1: Is there use of job rotation between explorative product } \\
\text { innovation activities/units and exploitative process innovation } \\
\text { activities/units? How is the use of this mechanism guaranteed? * } \\
\text { How intensely does the company use this mechanism? * }\end{array}$ & Jansen et al. (2009); Güttel et al. (2015) \\
\hline & $\begin{array}{l}\text { After stage 1: MCFI2: I Is there involvement of people related to } \\
\text { exploitative process innovation activities in explorative product } \\
\text { innovation activities for knowledge exchange? }\end{array}$ & Mechanisms added by respondents in stage 1 \\
\hline & $\begin{array}{l}\text { MCFI3: Is there use of regular collaboration between the } \\
\text { exploitative and explorative process innovation activities/units? }\end{array}$ & Jansen et al. (2009); Gassmann et al. (2012) \\
\hline & $\begin{array}{l}\text { MCFI4: Is there use of cross-functional teams with connections } \\
\text { between explorative product innovation activities/units and } \\
\text { exploitative process innovation activities/units? }\end{array}$ & $\begin{array}{l}\text { Jansen et al. (2009); Colombo et al. (2014); Xu } \\
\text { et al. (2017) }\end{array}$ \\
\hline & $\begin{array}{l}\text { MC1: Is there regular information exchange between explorative } \\
\text { product innovation activities/units and exploitative process } \\
\text { innovation activities/units? }\end{array}$ & $\begin{array}{l}\text { Jansen et al. (2006); Jansen et al. (2009); Su et } \\
\text { al., (2011); Gassmann et al. (2012); Colombo } \\
\text { et al. (2014); Chang \& Hughes (2014); Wang } \\
\text { \& Rafiq (2014); Güttel et al. (2015); Xu et al., } \\
\text { (2017) }\end{array}$ \\
\hline & $\begin{array}{l}\text { Before stage } 1 \text { - Is there use of regular goals and objectives } \\
\text { sharing? } \\
\text { After stage } 1 \text { - MC2: Are the goals of radical/new product } \\
\text { innovation for new customers used for focusing exploitative } \\
\text { process innovation activities? }\end{array}$ & $\begin{array}{l}\text { Mechanism changed due to the responses in } \\
\text { stage } 1 \\
\text { Jayawarna \& Holt (2009); Gassmann et al. } \\
\text { (2012); Chen \& Kannan-Narasimhan (2014); } \\
\text { Xu et al., (2017) }\end{array}$ \\
\hline
\end{tabular}




\begin{tabular}{|c|c|c|}
\hline Characteristics & Question & Comments/Authors \\
\hline & $\begin{array}{l}\text { Before stage 1: Is there use of regular information exchange } \\
\text { between exploitative process and explorative product innovation } \\
\text { activities/units? } \\
\text { After stage 1:MC3: Is knowledge of radical/new product } \\
\text { innovation for new customers incorporated into reports and } \\
\text { databases, among others, for later access for exploitative process } \\
\text { innovation activities? }\end{array}$ & $\begin{array}{l}\text { Mechanism changed due to the responses in } \\
\text { stage } 1 \\
\text { Jansen et al. (2006); Jansen et al. (2009); Su et } \\
\text { al., (2011); Gassmann et al. (2012); Colombo } \\
\text { et al. (2014); Chang \& Hughes (2014); Wang } \\
\text { \& Rafiq (2014); Güttel et al. (2015); Xu et al., } \\
\text { (2017) }\end{array}$ \\
\hline & $\begin{array}{l}\text { MC4: Are there communication and meetings between } \\
\text { people from exploitative process innovation activities/unit and } \\
\text { explorative product innovation activities/unit? }\end{array}$ & $\begin{array}{l}\text { Westerman et al. (2006); Jayawarna \& Holt } \\
\text { (2009); Gütttel et al. (2015) }\end{array}$ \\
\hline & $\begin{array}{l}\text { Before stage 1: Is there consolidation of a culture of freedom for } \\
\text { people to feel free to get in touch and share knowledge as needed } \\
\text { with people from other units/ projects? } \\
\text { After stage 1: MC5: Is there a free flow of ideas and information } \\
\text { from exploitative process innovation activities/units to explorative } \\
\text { product innovation activities/units? }\end{array}$ & $\begin{array}{l}\text { Mechanism changed due to the responses in } \\
\text { stage } 1 \text { in stage } 1 \\
\text { Jansen et al. (2009); Colombo et al. (2014); } \\
\text { Wang \& Rafiq (2014); Gütttel et al. (2015); Xu } \\
\text { et al., (2017) }\end{array}$ \\
\hline & $\begin{array}{l}\text { Before stage 1: Is there consolidation of a culture of freedom for } \\
\text { people to feel free to get in touch and share knowledge as needed } \\
\text { with people from other units/projects? } \\
\text { After stage 1: MC6: Is there encouragement of ideas and } \\
\text { contributions from exploitative process innovation activities/units } \\
\text { to support explorative product innovation activities/units? }\end{array}$ & $\begin{array}{l}\text { Mechanism changed due to the responses in } \\
\text { stage } 1 \text { in stage } 1 \\
\text { Jansen et al. (2009); Colombo et al. (2014); } \\
\text { Wang \& Rafiq (2014); Gütttel et al. (2015); Xu } \\
\text { et al., (2017) }\end{array}$ \\
\hline & $\begin{array}{l}\text { MC7: Are there decision-making committees with people from } \\
\text { exploitative process innovation activities/units and explorative } \\
\text { product innovation activities/units? }\end{array}$ & Mechanisms added by respondents in stage 1 \\
\hline $\begin{array}{l}\text { Benefits of the } \\
\text { integration } \\
\text { between } \\
\text { exploitative } \\
\text { process } \\
\text { innovation and } \\
\text { explorative } \\
\text { product } \\
\text { innovation }\end{array}$ & $\begin{array}{l}\text { Before stage 1: What are the benefits of the integration between } \\
\text { exploitative process innovation and explorative product } \\
\text { innovation? What are the mechanisms that most help in } \\
\text { achieving these benefits? } \\
\text { After stage 1: B1: Is there a reduction in the development time of } \\
\text { radical/new products for new customers? } \\
\text { After stage 1: B2: Is there a better quality of radical/new products } \\
\text { for new market innovations? } \\
\text { After stage 1: B3: Is there a better decision-making process for } \\
\text { product innovation projects considering exploitative innovation } \\
\text { activities? } \\
\text { After stage 1: B4: Is there greater process support for the } \\
\text { development and implementation of radical/new product } \\
\text { innovation for new customers? } \\
\text { What are the mechanisms that most help in achieving these } \\
\text { benefits? }\end{array}$ & $\begin{array}{l}\text { Benefits were changed due to the responses in } \\
\text { stage } 1 \text { in stage } 1\end{array}$ \\
\hline
\end{tabular}

\footnotetext{
* Questions asked for all mechanisms
} 
All the interviews were transcribed and the statements about the mechanisms were fragmented into single signatures to enable a better understanding and compilation of the use of the mechanisms. This procedure allowed for an in-depth and general view of each of the cases, besides enabling the use of the integration mechanisms and the relationship of these with the benefits to be deducted.

\section{Field Research}

\section{I Characteristics of the companies studied}

The study examined four large Brazilian companies. They are considered innovation leaders in their segments. Table 3 presents an overview of the companies studied and of the respondents. Each company has a research and development unit in Brazil (usually focused on product R\&D) and develops radical and incremental products, process innovation activities, and research into new technologies.

Table 3

\section{Overview of the companies studied}

\begin{tabular}{|c|c|c|c|c|}
\hline Features & Company A & Company B & Company $\mathrm{C}$ & Company D \\
\hline Nationality & Multinational & Multinational & Multinational & National \\
\hline Sector & Consumer goods & Appliances & Chemical & Cosmetics \\
\hline Interviews & $\begin{array}{l}\text { R\&D Lab Manager, } 2 \\
\text { Technical Experts (R\&D), } \\
\text { Manufacturing Engineer, } \\
\text { Project Manager }\end{array}$ & $\begin{array}{l}\text { Project Coordinator, } \\
\text { Senior Manager of } \\
\text { Product Development, } \\
\text { Process Engineer, } \\
\text { Project Manager }\end{array}$ & $\begin{array}{l}\text { Innovation Excellence } \\
\text { Manager, Senior } \\
\text { Process Engineer, } \\
\text { Project Manager } \\
\text { of Operational } \\
\text { Excellence, Senior } \\
\text { Researcher (R\&D) }\end{array}$ & $\begin{array}{l}\text { Innovation Project } \\
\text { Manager, Coordinator of } \\
\text { Manufacturing Processes, } \\
\text { Process Engineer, } \\
\text { Technology Engineer }\end{array}$ \\
\hline $\begin{array}{l}\text { Locus of explorative } \\
\text { product innovation } \\
\text { activities }\end{array}$ & $\begin{array}{l}\text { Research and Development } \\
\text { Center (Lab) }\end{array}$ & $\begin{array}{l}\text { Product Development } \\
\text { unit }\end{array}$ & $\begin{array}{l}\text { Development Product } \\
\text { Center in the R\&D } \\
\text { unit }\end{array}$ & Innovation unit \\
\hline $\begin{array}{l}\text { Locus of exploitative } \\
\text { product innovation } \\
\text { activities }\end{array}$ & $\begin{array}{l}\text { Research and Development } \\
\text { Center (Lab) }\end{array}$ & $\begin{array}{l}\text { Product Development } \\
\text { unit }\end{array}$ & $\begin{array}{l}\text { Development Product } \\
\text { Center in the R\&D } \\
\text { unit }\end{array}$ & $\begin{array}{l}\text { Formula Development } \\
\text { area }\end{array}$ \\
\hline $\begin{array}{l}\text { Locus of exploitative } \\
\text { process innovation } \\
\text { activities }\end{array}$ & Manufacturing unit & Industrial unit & Industrial division & Industrial unit \\
\hline
\end{tabular}

\section{Company $A$}

Exploitative product innovation activities involve adapting the product to the national, existent market with small changes in materials and suppliers, and with product enhancements and/or performance modifications. Explorative product innovation activities involve new products for new markets or product adaptations for new markets. All projects related to products are developed in the Research and Development Center, also called the Lab, with multifunctional teams. Exploitative process innovation projects take place in the manufacturing unit with the support of Six Sigma and Lean principles. 


\section{Company B}

Explorative product innovation activities involve the use of new technologies and subsequent applications to new products, and high levels of employee resources, risk, and time. New developments would occur under an existing product platform (architectural innovation). Exploitative product innovation activities involve small changes in existent products. Both activities occur in the Product Development unit. Considering the activities related to explorative product innovation, there is a general management for the developments and portfolio managers for each of the company's businesses. Exploitative innovation activities are under the responsibility of the product engineering manager.

Exploitative process innovation activities are led by the industrial engineering unit, with the support of Six Sigma and Lean projects to improve processes, reduce variability and costs, and increase productivity and quality of the products.

There are company employee forums and committees to enable coordination, collaboration, and alignment between areas such as development, manufacturing, quality, and product engineering, and between exploitative and explorative activities.

\section{Company $C$}

Exploitative product innovation aims to respond to business opportunities, which are usually specific requests from existent customers, and these activities occur in the industrial area. The activities use known technology, functions, and product formulations. The explorative product innovation adapts technologies and develops knowledge to meet identified customer and market needs, or to create long-term trends that result in competitive advantage for the company. These activities occur in the R\&D unit.

The company uses committees for monitoring and decision making on innovation activities. In the innovation committee, decisions are made regarding the continuity of projects and the integration of new projects. The committee members are directors of research, industrial, and business sectors, the industrial manager, the processes engineer from $\mathrm{R} \& \mathrm{D}$, and project leaders, among others. Participants bring information from their areas and customers, new ideas are encouraged during the meetings, and the committee decides whether the chosen projects will be developed in the industrial area (exploitative product innovation) or as $\mathrm{R} \& \mathrm{D}$ projects (explorative product innovation projects). Ideas are generated and can foster exploitative or explorative activities, generating possible connections between projects.

Regarding exploitative process innovation activities, the leaders of these types of projects are the engineers of industrial processes allocated to the industrial division. These are projects focused on process safety and improvement, and may be Six Sigma, Lean, Kaizen, etc.

\section{Company D}

Explorative product innovation involves new knowledge, raw materials, and formulas, and efforts in several areas of research and development. Incremental product innovations are small changes in current formulations of the products, which are short-term projects and less complex. Explorative product innovation projects occur in the Innovation unit, while exploitative product innovation is the responsibility of the Formula Development area, which addresses a request and uses a reference product as appointed by the marketing team. The Packaging Development area also participates in the developments according to the needs and concept to be followed.

Exploitative process innovation activities occur in the Industrial unit under the responsibility of the industrial management. The projects involve process improvement teams trained in concepts and participating in approaches such as TPM, Kaizen, Six Sigma, and Lean-Sigma.

\subsection{Data analysis}

The mechanisms found in the literature were adapted for the relationships, and mechanisms 
identified in preliminary interviews (stage 1) were added. The analysis of the mechanisms' presence was based on the respondents' most frequently recurring answers about the existing presence level of the mechanisms. We classified the answers into four distinct levels: high, medium, low, and non-existent. The data were compiled by observing both the interviewee's answer about the mechanisms' presence level and the interviewee's general comments on how these mechanisms were developed in the company.

The mechanisms were identified, first, in the literature. Six integration mechanisms were identified or modified in the companies in the preliminary interviews (MCFI2 and MC2 - companies B and C; MC3, MC4, MC6, and MC7 - companies A and C), which necessitated an adjustment of the questionnaire and a new round of questions for the respondents. The modifications and inclusions are presented in table 2.

Three of the companies studied (A, $B$, and C) do not have separate units for exploration and exploitation product innovation activities: improvement and new/radical product developments are in the same unit. Job rotation was among the Cross-Functional Interface mechanisms that presented the most deployment difficulty. Despite assertions by all the companies that they have this practice, it is still difficult to integrate the activities of exploration and exploitation. One explanation for this difficulty is the technical expertise required for each function (company D). Employee involvement in development teams is higher in the companies that do not have structural separation (A, B, and C) because employees work together more closely, and teams already rely on the participation of their people in exploitative product innovation activities.

Considering Cross-Functional Interface mechanisms, the companies encourage the use of regular collaboration and the involvement of people related to the exploitative product innovation in the explorative product innovation
(MCFI2 and MCFI3). Company A points out that there is a collaborative network between people who are working with the same material or product, regardless of whether they are engaged in activities of exploitative or explorative product innovation. There is low use of regular job rotation between exploitative and explorative product innovation activities/units. The respondents of company C claim that people related to exploitative product innovation are more involved in technical aspects and not in the development of new formulations and materials, making job rotation difficult in the company.

The companies highly encourage connectedness mechanisms involving the flow of information and ideas (MC1, MC6, and MC7). The interview comments reveal that ideas and knowledge from exploitative product innovation can contribute to explorative product innovations. In company $\mathrm{D}$, incremental innovations are more related to formula changes where the product does not differ from its original concept, so there is less interest in these integration mechanisms. In companies $\mathrm{A}$ and $\mathrm{C}$, exploitative product innovation activities may generate ideas for explorative product innovations. The products in company B consist of several subsystems, and the results of exploitative innovations may be inputs into explorative product innovations.

It is not common to have common targets (MC2), but exploitative innovation can assist in achieving the quality goals of products generated in explorative innovation. Placing information in a database for later access (MC3, MC4) is highly encouraged to facilitate knowledge exchange about what is happening in the company and encourage creativity. Meetings, forums, and innovation committees (MC5) are the main methods for coordinating the actions of collaborative projects identified in both innovation activities - exploitative and explorative.

The summary of the use of integration mechanisms between exploitative product innovation and explorative product innovation activities can be seen in table 4 . 
Table 4

Use of integration mechanisms between exploitative and explorative product innovation activities

\begin{tabular}{|c|c|c|c|c|}
\hline \multirow{2}{*}{ Mechanisms (M) } & \multicolumn{4}{|c|}{ Company } \\
\hline & A & B & $\mathrm{C}$ & D \\
\hline $\begin{array}{l}\text { MCFI1: Use of regular job rotation between exploitative and explorative product } \\
\text { innovation activities/units }\end{array}$ & Medium & Medium & Low & Low \\
\hline $\begin{array}{l}\text { MCFI2: Involvement of people related to the exploitative product innovation } \\
\text { activities in the explorative product innovation activities for knowledge exchange }\end{array}$ & High & High & High & Low \\
\hline $\begin{array}{l}\text { MCFI3: Use of regular collaboration between people from the exploitative and } \\
\text { explorative product innovation activities/units }\end{array}$ & High & High & High & Low \\
\hline $\begin{array}{l}\text { MCFI4: Use of cross-functional teams with connections between explorative } \\
\text { product innovation activities/unit and exploitative product innovation activities/unit }\end{array}$ & Medium & High & High & Low \\
\hline $\begin{array}{l}\text { MC1: Use of regular information exchange between exploitative and explorative } \\
\text { product innovation activities/units }\end{array}$ & High & High & High & Low \\
\hline $\begin{array}{l}\text { MC2: Use of the goals of new product innovation for new customers to focus } \\
\text { exploitative product innovation activities }\end{array}$ & Low & Medium & Medium & Low \\
\hline $\begin{array}{l}\text { MC3: Incorporation of knowledge from radical/new product innovation for new } \\
\text { customers into reports and databases, among others, for later access for exploitative } \\
\text { product innovation activities }\end{array}$ & High & Medium & High & High \\
\hline $\begin{array}{l}\text { MC4: Incorporation of knowledge from incremental product innovations into } \\
\text { reports and databases, among others, for later access for explorative product } \\
\text { innovation activities }\end{array}$ & High & Medium & High & High \\
\hline $\begin{array}{l}\text { MC5: Communication and meetings (including forums and committees) between } \\
\text { people from exploitative and explorative product innovation activities/units }\end{array}$ & Medium & High & High & Medium \\
\hline $\begin{array}{l}\text { MC6: Generating free flow of ideas and information from exploitative product } \\
\text { innovation activities/units to explorative product innovation activities/units }\end{array}$ & High & High & High & High \\
\hline $\begin{array}{l}\text { MC7: Encouraging ideas and contributions from exploitative product innovation } \\
\text { activities/units to explorative product innovation activities/units }\end{array}$ & High & High & High & Medium \\
\hline
\end{tabular}

The reported benefits include incorporating improvement features developed in explorative product innovation into existing products (mainly related to the mechanisms MCIF4, MC1, and MC3), the development of radical product innovation in explorative innovation activities incorporating improvements proposed by the market or internally (MCFI2, MCIF4, MC5,
MC6, and MC7), and faster development of radical products (MCIF4, MC1, and MC5). Integration mechanisms enable collaboration and connection between activities, improving both existing products as well as radically innovative products. The benefits reported by the respondents are shown in table 5. Greater use of mechanisms led to greater reported benefits. 
Table 5

Benefits of using integration mechanisms (relationship I)

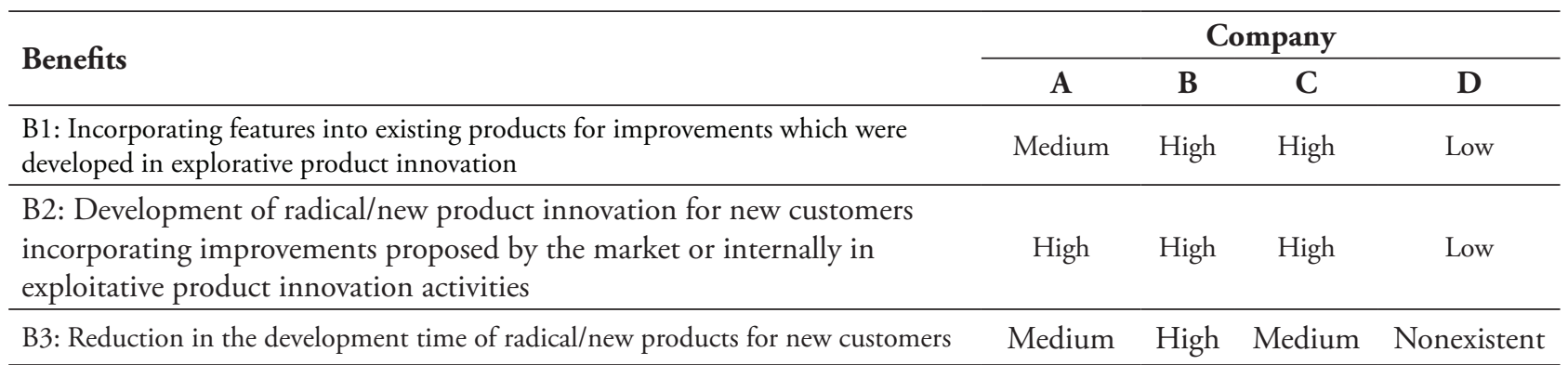

The unit responsible for exploitative process innovation, usually associated with improvement programs, was separated from product $\mathrm{R} \& \mathrm{D}$ units in all companies. Mechanisms were identified in the literature and during the preliminary interviews (stage 1) (MC2 - company B; MCFI2, MC3, MC5, MC6, and MC7 company $\mathrm{C}$ ). A compilation of the mechanisms and the modifications generated are presented in table 2 .

In this case, the four companies each have structural separation between exploitation and exploration units (product R\&D units are separate from exploitative process innovation). Observing Cross-Functional Interface mechanisms, job rotation is non-existent in three of the companies, most likely because of the very distinct training required to perform those functions. In the company with the lowest job rotation (company $C)$, people who work in the industrial division and R\&D unit sometimes have similar professional qualifications, namely as chemical engineers.

The use of cross-functional teams (MCFI4) brings the exploitative process innovation unit closer to the R\&D unit (explorative product innovation unit), allowing them to assist with minor adjustments and process improvements for new developments, or even to implement radical changes. Despite the use of cross-functional teams, there remain difficulties in setting up collaboration mechanisms (MCFI3 and MCFI4), as it depends on the company culture and how processes can influence or assist in product innovation outputs.

Regarding Connectedness mechanisms, information exchange (MC1) is made possible by informal contacts between teams and meetings between people from exploitative process innovation activities/units and explorative product innovation activities/units (MC4). These meetings include team members, not just top management. Top management are involved in decision-making committees (MC7) in companies $\mathrm{B}$ and $\mathrm{C}$, which helps drive actions and shared goals (MC2).

Because database platforms are often different for each activity, knowledge of product innovation activities is generally not incorporated into data platforms that can be mutually accessed by the people involved with exploitative process innovation (MC3). However, the units are already connected to generate a free flow of ideas (MC5) and encourage ideas and contributions (MC6), as the benefits of directly supporting exploitation process innovation activities for explorative product activities and radical product innovation are already being realized.

A summary of the use of integration mechanisms between exploitative process innovation activities and explorative product innovation can be seen in table 6 . 
Table 6

Use of integration mechanisms between exploitative process innovation and explorative product innovation activities

\begin{tabular}{|c|c|c|c|c|}
\hline \multirow{2}{*}{ Mechanisms (M) } & \multicolumn{4}{|c|}{ Company } \\
\hline & A & B & $\mathrm{C}$ & D \\
\hline $\begin{array}{l}\text { MCFI1: Use of job rotation between explorative product innovation } \\
\text { activities/units and exploitative process innovation activities/units }\end{array}$ & Nonexistent & Nonexistent & Low & Nonexistent \\
\hline $\begin{array}{l}\text { MCFI2: Involvement of people related to exploitative process } \\
\text { innovation activities in explorative product innovation activities for } \\
\text { knowledge exchange }\end{array}$ & High & Medium & High & Low \\
\hline $\begin{array}{l}\text { MCFI3: Use of regular collaboration between the exploitative and } \\
\text { explorative process innovation activities/units }\end{array}$ & High & Medium & High & Low \\
\hline $\begin{array}{l}\text { MCFI4: Use of cross-functional teams with connections between } \\
\text { explorative product innovation activities/units and exploitative process } \\
\text { innovation activities/units }\end{array}$ & High & High & High & High \\
\hline $\begin{array}{l}\text { MC1: Enabling regular information exchange between explorative } \\
\text { product innovation activities/units and exploitative process innovation } \\
\text { activities/units }\end{array}$ & Medium & Medium & High & Nonexistent \\
\hline $\begin{array}{l}\text { MC2: Use of the goals of radical/new product innovation for new } \\
\text { customers to focus exploitative process innovation activities }\end{array}$ & Low & Medium & High & Low \\
\hline $\begin{array}{l}\text { MC3: Incorporation of knowledge from radical/new product } \\
\text { innovation for new customers into reports and databases, among others, } \\
\text { for later access for exploitative process innovation activities }\end{array}$ & Low & Low & Medium & Low \\
\hline $\begin{array}{l}\text { MC4: Communication and meetings between people from exploitative } \\
\text { process innovation activities/units and explorative product innovation } \\
\text { activities/units }\end{array}$ & Medium & Medium & High & Low \\
\hline $\begin{array}{l}\text { MC5: Generating the free flow of ideas and information from } \\
\text { exploitative process innovation activities/units to explorative product } \\
\text { innovation activities/units }\end{array}$ & Medium & Medium & High & Low \\
\hline $\begin{array}{l}\text { MC6: Encouraging ideas and contributions from exploitative process } \\
\text { innovation activities/units to support explorative product innovation } \\
\text { activities/units }\end{array}$ & High & Medium & High & Low \\
\hline $\begin{array}{l}\text { MC7: Decision-making committees with people from exploitative } \\
\text { process innovation activities/units and explorative product innovation } \\
\text { activities/units }\end{array}$ & Nonexistent & Medium & High & Nonexistent \\
\hline
\end{tabular}

A greater the dependency between exploitation process activities and exploration product activities corresponds to a greater need for integration mechanisms, as their use enables benefits such as reduced time for product innovation (associated with MCFI4, MC1, and MC4), higher product quality (associated with MCFI2, MCFI3, MCFI4, MC1, and MC4), better decision-making processes for product innovation projects considering production processes of exploitative innovation activities (associated with MCFI2, MCFI4, MC4, and MC7), and greater support for explorative product innovation activities (associated with MC3, MC5, MC6, and MC7). The benefits are summarized in table 7. 
Table 7

Benefits of using integration mechanisms (relationship II)

\begin{tabular}{|c|c|c|c|c|}
\hline \multirow{2}{*}{ Benefits } & \multicolumn{4}{|c|}{ Company } \\
\hline & A & B & $\mathrm{C}$ & $\mathbf{D}$ \\
\hline B1: Reduction in the development time of radical/new products for new customers & Medium & Medium & High & Low \\
\hline B2: Higher quality of radical/new product for new markets innovations & Medium & High & High & Medium \\
\hline $\begin{array}{l}\text { B3: Better decision-making process for product innovation projects considering } \\
\text { processes of exploitative innovation activities }\end{array}$ & High & High & High & High \\
\hline $\begin{array}{l}\text { B4: Greater process support for the development and implementation of radical/new } \\
\text { product innovation for new customers }\end{array}$ & Medium & Medium & High & Low \\
\hline
\end{tabular}

The analysis of the data shows that both mechanisms of cross-functional interfaces and of connectedness, as established by Jensen et al. (2009), are important and used for the integration of the relationships, as well as both helping in the generation of benefits. For the relationship between exploitative and explorative product innovation activities, the mechanisms "the involvement of people related to the exploitative product innovation activities in the explorative product innovation activities for knowledge exchange" (MCFI2) are well used, because some already existent products are related to new products, therefore there is an important knowledge exchange, as proposed by Jansen et al. (2009) and Gassmann et al. (2012). Another important mechanism is the "use of regular collaboration between people from the exploitative and explorative product innovation" (MCFI3) proposed by the respondents and not identified in the literature review. Two connectedness mechanisms, "generating the free flow of ideas and information" (MC6) and "encouraging ideas and contributions" (MC7), were also well used by the companies and were also modified by the respondents, being closer to the reality of the analyzed relationship, but maintaining the importance of the culture of freedom dimension for integration, as already pointed out by Jansen et al. (2009), Colombo et al. (2014), Wang \& Rafiq (2014), Gütttel et al. (2015), and Xu et al. (2017). The exchange of information, made possible by reports and databases, among others (MC3, MC4), are is also another mechanism modified by the respondents, but associated with the literature that shows the importance of formal and informal connectedness for knowledge exchange (Chen \& Kannan-Narasimhan, 2014; Colombo et al., 2014; Gütttel et al., 2015; Jansen et al., 2009; Westerman et al., 2006).

Considering the second relationship between exploitative process innovation activities and explorative product innovation activities, in general, the mechanisms are less used than for the first relation. This may be due to the proximity between exploitative product innovation activities and explorative product innovation activities. Observing cross-functional interface mechanisms, the most used is "use of cross-functional teams with connections between explorative product innovation activities/units and exploitative process innovation activities/units" (MC4). This high use may be due to the use of cross-functional teams to develop products that bring people related to the activities of exploitative process innovation. The importance of this mechanism had already been highlighted in the literature due to the possibility of information exchange of knowledge and experiences (Colombo et al., 2014; Jansen et al., 2009; Xu et al., 2017). Other important cross-functional interface mechanisms are "involvement of people related to exploitative process innovation activities in explorative product innovation activities for knowledge exchange" (MCFI2) and "use of regular collaboration between the exploitative and explorative process innovation activities/units" (MCFI3). Observing connectedness mechanisms, 
again there is an emphasis on cultural aspects, and "encouraging ideas and contributions from exploitative process innovation activities/units to support explorative product innovation activities/ units" (MC6). However, for this relationship, the cross-functional interface mechanisms are more used than connectedness mechanisms, showing the importance of the proximity of the teams and individuals related to the different activities.

\section{Conclusions}

\section{I Theoretical Contributions}

Prior literature has emphasized the benefits to an organization's performance of adopting multiple types of innovation (Prange \& Schlegelmilch, 2016) and the importance of simultaneity between exploitative and explorative innovation (He \& Wong, 2004; Rothaermel \& Deeds, 2004) Other authors also emphasize the need to balance exploitation and exploration for company success (Benner \& Tushman, 2003; Smith \& Tushman, 2005; Tushman \& O’Reilly, 1996). However, despite the importance of the coexistence between exploitative innovation activities and explorative innovation activities, there are no studies on the integration of these activities at the level of the individual and the impacts generated by the integration (Colombo et al., 2014; Gassmann et al., 2012).

When the integration theme is addressed in the context of exploitation-exploration innovation this is related to integration at the top management level, to cooperate in relation to important resources, such as financial resources, knowledge, skills, and clients (Gibson \& Birkinshaw, 2004; He \& Wong, 2004; O’Reilly \& Tushman, 2004; Tushman \& O’Reilly, 1996). There are few studies on integration at the team or individual levels and there are no studies about practices or mechanisms that can foster such integration (Colombo et al., 2014; Gassmann et al., 2012; Jansen et al., 2009). There are even fewer studies when we observe the division of explorative innovation activities and exploitative innovation activities considering the products and processes perspective proposed by some authors (Bauer \& Leker, 2013; Lin \& McDonough, 2011; Wang \& Rafiq, 2014). Therefore, there are substantial contributions to be made to the literature.

The integration mechanisms related to exploration-exploitation innovation were identified in the literature and although there are few studies, compiling such mechanisms can foster future research. In addition, the mechanisms were confirmed and analyzed in a field study, which enabled the research to be carried out contemplating not only the division between exploitative and explorative innovation activities, but also including the division between product and process innovation.

The research makes advances by showing that there are relationships between exploitative and explorative product innovation activities and between exploitative process innovation and explorative product innovation activities (relationships proposed by Bauer \& Leker, 2013; Lin \& McDonough, 2011; Piao \& Zajac, 2016; Prange \& Schlegelmilch, 2016; Rothaermel \& Deeds, 2004). This was confirmed by four case studies identifying the benefits generated by these relationships and thus contributing to the research. The mechanisms were adapted at the suggestion of the interviewees and new mechanisms were suggested, but one of the most important points regarding the literature was the adaptation of the mechanisms for the observed relations, between exploitative process innovation and explorative product innovation and exploitative product innovation and explorative product innovation.

All the companies presented mechanisms for integrating exploitation and exploration independently of the relationship analyzed. Observing the relationship between exploitative product innovation and explorative product innovation and considering cross-functional interface mechanisms, the most used mechanisms were those related with collaboration and involvement for knowledge exchange. Considering 
connectedness mechanisms, the most applied were the mechanisms related to cultural issues: enabling the free flow of ideas and encouraging new ideas and the exchange of formal knowledge. The most apparent benefit is the development of radical innovation incorporating improvements proposed by the market or internally in exploitative product innovation activities, and this benefit is associated with collaboration, culture, and alignment via forums and committees.

Observing the relationship between exploitative process innovation and explorative product innovation and considering crossfunctional interface mechanisms, the most used mechanism is cross-functional teams, which enables other mechanisms, such as collaboration and involvement for knowledge exchange. Considering connectedness mechanisms, the most applied are also the mechanisms related to cultural issues: enabling the free flow of ideas and encouraging new ideas and communication and meetings between people from exploitative process innovation activities/units and explorative product innovation activities/units. The most apparent benefit is the better decision-making for product innovation projects considering production process exploitative innovation activities and this benefit is associated with collaboration, cross-functional teams, culture, and alignment via forums and committees.

Therefore, regardless of the relationship, the mechanisms most used by the companies are regular collaboration, involvement for knowledge exchange (cross-functional interface mechanisms), those related to a culture of freedom, such as the free flow and encouragement of ideas, and those related to knowledge and information exchange (connectedness mechanisms).

There is a theoretical gap in the literature, in that the possible benefits generated by the relationships are not presented nor are the mechanisms that allow for the generation of these benefits. This paper tries to explore and make advances in this subject. We noticed that the contribution of the mechanisms is dependent on the product manufactured by the company and the context in which it operates; this area requires further investigation by future research.

There are limitations in the research. First, the data are restricted to a small group of Brazilian organizations that are focusing on product and process innovations. This reduces the generalizability of the results to other settings. However, organizations from different industries were included in the investigated sample to make our findings generalizable to a broad group of organizations. Future studies should examine whether these integration mechanisms are applicable in other contexts and whether the same benefits are found in other settings. Future work should also look at the relationships between mechanisms and benefits in a more quantitative way to identify relationships and allow for greater generalizations.

\subsection{Managerial implications}

In addition to the contributions to the literature, the research has important managerial implications. The adoption of multiple innovations and the integration between exploitation and exploration, considering product and process innovation, has been shown to play a crucial role in organizational survival, but little is known about the integration mechanisms between them and the benefits of integration. This research sheds new light on these relationships, mechanisms, and benefits. We have shown that it is possible to integrate exploitative and explorative innovation activities at the team and individual levels. The benefits from using integration mechanisms that were identified highlight the fact that iterations between exploration and exploitation are a key driving force in the product innovation process.

In practice, the findings can help to implement a range of mechanisms that can assist in the integration of exploitative and explorative activities. The results of the research make it possible to understand that integration must take place at the team and individual levels, and not only at the top management level. Moreover, 
integration between exploitative process and explorative product innovation and between exploitative product innovation and explorative product innovation are beneficial for the company.

This research assists by showing the contributions of organizational integration mechanisms for innovation and by proposing relationships among distinct types of innovation observed using the exploration-exploitation concept. The managerial implications lie in the perception that integration between these activities, although they often seen as separate and without collaboration, can be beneficial, and specific mechanisms can be used to foster such integration.

\section{References}

Adler, P. S., Goldoftas, B., \& Levine, D. I. (1999). Flexibility versus efficiency? A case study of model changeovers in the Toyota production system. Organization Science, 10(1), 43-68. doi: 10.1287/ orsc. 10.1 .43

Andriopoulos, C. \& Lewis, M. W. (2009). Exploitation-exploration tensions and organizational ambidexterity: Managing paradoxes of innovation. Organization Science, 20(4), 696717. doi: $10.1287 /$ orsc. 1080.0406

Andriopoulos, C. \& Lewis, M. W. (2010). Managing innovation paradoxes: Ambidexterity lessons from leading product design companies. Long Range Planning, 43(1), 104-122. doi: 10.1016/j.lrp.2009.08.003

Atuahene-Gima, K. (2005). Resolving the capability_rigidity paradox in new product innovation. Journal of Marketing, 69(4), 61-83. doi: 10.1509/jmkg.2005.69.4.61

Bauer, M., \& Leker, J. (2013). Exploration and exploitation in product and process innovation in the chemical industry. R\&D Management, 43(3), 196-212. doi: 10.1111/radm.12012

Benner, M. J., \& Tushman, M. L. (2002). Process management and technological innovation: A longitudinal study of the photography and paint industries. Administrative Science Quarterly, 47(4), 676-707. doi: 10.2307/3094913

Benner, M. J.\& Tushman, M. L. (2003). Exploitation, exploration, and process management: The productivity dilemma revisited. Academic Management Review, 28(2), 238-256. doi: $10.2307 / 30040711$

Benner, M. J., \& Tushman, M. L. (2015). Reflections on the 2013 decade award"exploitation, exploration, and process management: The productivity dilemma revisited" ten years later. Academy of Management Review, 4O(4), 497-514. doi: 10.5465/amr.2015.0042

Birkinshaw, J., \& Gibson, C. (2004). Building ambidexterity into an organization topic: Leadership and organizational studies. Sloan Management Review, Summer(4), 47-55. doi: $10.2307 / 20159573$

Blindenbach-Driessen, F., \& Ende, J. (2014). The locus of innovation: The effect of a separate innovation unit on exploration, exploitation, and ambidexterity in manufacturing and service firms. Journal of Product Innovation Management, 31(5), 1089-1105. doi: 10.1111/jpim.12146

Bogers, M., \& Lhuillery, S. (2011). A functional perspective on learning and innovation: Investigating the organization of absorptive capacity. Industry and innovation, 18(6), 581-610. doi: 10.1080/13662716.2011.591972

Boland, R. J., Jr, Lyytinen, K., \& Yoo, Y. (2007). Wakes of innovation in project networks: The case of digital 3-D representations in architecture, engineering, and construction. Organization science, 18(4), 631-647. doi: 10.1287 /orsc. 1070.0304

Chang, Y. Y., \& Hughes, M. (2012). Drivers of innovation ambidexterity in small-to mediumsized firms. European Management Journal, 30(1), 1-17. doi: 10.1016/j.emj.2011.08.003 
Chen, R. R., \& Kannan-Narasimhan, R. P. (2015). Formal integration archetypes in ambidextrous organizations. R\&D Management, 45(3), 267-286. doi:10.1111/radm.12083

Christensen, C. M. (1997). The Innovator's Dilemma: When New Technologies Cause Great Firms to Fail, Harvard University Press, Boston, MA.

Colombo, M. G., Doganova, L., Piva, E., D’Adda, D., \& Mustar, P. (2015). Hybrid alliances and radical innovation: The performance implications of integrating exploration and exploitation. The Journal of Technology Transfer, 40(4), 696-722. doi:10.1007/s10961-014-9363-x

Derbyshire, J. (2014). The impact of ambidexterity on enterprise performance: Evidence from 15 countries and 14 sectors. Technovation, 34(10), 574-581. doi: 10.1016/j. technovation.2014.05.010

Duncan, R. B. 1976. The ambidextrous organization: Designing dual structures for innovation. In R. H. Kilmann, L. R. Pondy, \& D. P. Slevin (Eds.), The management of organization design: Strategy and implementation (Vol. 1, pp. 167-188). New York: North-Holland.

Eisenhardt, K. M. (1989). Building theories from case study research. Academy of management review, 14(4), 532-550. doi: 10.5465/amr.1989.4308385

Garcia, R., \& Calantone, R. (2002). A critical look at technological innovation typology and innovativeness terminology: A literature review. Journal of product innovation management, 19(2), 110-132. doi: 10.1111/1540-5885.1920110

Gassmann, O., Widenmayer, B., \& Zeschky, M. (2012). Implementing radical innovation in the business: The role of transition modes in large firms. R\&D Management, 42(2), 120-132. doi: 10.1111/j.1467-9310.2011.00670.x

Gibson, C. B., \& Birkinshaw, J. (2004). The antecedents, consequences, and mediating role of organizational ambidexterity. Academy of management Journal, 47(2), 209-226. doi: $10.2307 / 20159573$

Gonzalez, R. V. D., \& Melo, T. M. D. (2018). Innovation by knowledge exploration and exploitation: An empirical study of the automotive industry. Gestão \& Produção, 25(1), 1-15.

Gupta, A. K., Smith, K. G., \& Shalley, C. E. (2006). The interplay between exploration and exploitation. Academy of Management Journal, 49(4), 693-706. doi: 10.5465/ amj.2006.22083026

Güttel, W. H., Konlechner, S. W., \& Trede, J. K. (2015). Standardized individuality versus individualized standardization: The role of the context in structurally ambidextrous organizations. Review of Managerial Science, 9(2), 261-284. doi:10.1007/s11846-014-0156-2

He, Z. H. \& Wong, P. K. (2004). Exploration vs. Exploitation: An empirical test of the ambidexterity hypothesis. Organization Science, 15(4), 481-494. doi: 10.1287/orsc. 1040.0078

Henderson, R. M., \& Clark, K. B. (1990). Architectural innovation: The reconfiguration of existing product technologies and the failure of established firms. Administrative science quarterly, 35(1)9-30. doi:10.2307/2393549

Huang, Y. C., Ma, R., \& Lee, K. W. (2015). Exploitative learning in project teams: Do cognitive capability and strategic orientations act as moderator variables?. International Journal of Project Management, 33(4), 760-771. doi:10.1016/j.ijproman.2014.10.004

Instituto Nacional da Propriedade Industrial (INPI) (2015). Indicadores de Propriedade Industrial (2000-2012). Rio de Janeiro: INPI Publishing.

Jansen, J. J. P., Tempelaar, M. P., Bosch, F. A. J., Van Den, \& Volberda, H. W. (2009). 
Structural differentiation and ambidexterity: The mediating role of integration mechanisms. Organization Science, 20(4), 797-811. doi: $10.1287 /$ orsc. 1080.0415

Jansen, J. J. P., Bosch, A. J., Van Den, \& Volberda, H. W. (2006). Exploratory Innovation, Exploitative Innovation, and Performance: Effects of Organizational Antecedents and Environmental Moderators. Management Science, 52(11), 16611674. doi: $10.1287 / \mathrm{mnsc} .1060 .0576$

Jayawarna, D., \& Holt, R. (2009). Knowledge and quality management: An R\&D perspective. Technovation, 29(11), 775-785. doi: 10.1016/j. technovation.2009.04.004

Lakemond, N., \& Detterfelt, J. (2013). Counterbalancing exploitative knowledge search during environmental dynamism: Reinforcing new ideas for existing products. Creativity and Innovation Management, 22(4), 420-434. doi:10.1111/caim.12038

Lin, H. E., \& McDonough, E. F., III. (2011). Investigating the role of leadership and organizational culture in fostering innovation ambidexterity. IEEE Transactions on engineering management, 58(3), 497-509. doi: 10.1109/ tem.2010.2092781

March, J. G. (1991). Exploration and exploitation in organizational learning. Organization Sciences, 2(1), 71-87. doi: 10.1287/orsc.2.1.71

Martini, A., Laugen, B.T., Gastaldi, L., \& Corso, M. (2013). Continuous innovation: Towards a paradoxical, ambidextrous combination of exploration and exploitation. International Journal Technology Management, 61(1), 1-22. doi: 10.1504/ijtm.2013.050246

Martins, E. S., Rosseto, C. R., Lima, N. C., \& Penedo, A. S. T. (2014). Comportamento estratégico e ambidestria: Um estudo aplicado junto às empresas vinícolas brasileiras. Revista Brasileira de Gestáo de Negócios, 16(52), 392-415. doi:10.7819/rbgn.v16i52.1540
Molina-Castillo, F. J., Jimenez-Jimenez, D., \& Munuera-Aleman, J. L. (2011). Product competence exploitation and exploration strategies: The impact on new product performance through quality and innovativeness. Industrial Marketing Management, 4O(7), 1172-1182. doi: 10.1016/j. indmarman.2010.12.017

Moreira, F. G., Torkomian, A. L. V., \& Soares, T. J. (2016). Exploration and firms' innovative performance-How does this relationship work?. Revista Brasileira de Gestão de Negócios, 18(61), 392-415. doi:10.7819/rbgn.v18i61.2635

O'Reilly, C. A., \& Tushman, M. L. (2004). The ambidextrous organization. Harvard Business Review, 82(4), 74-81.

O'Reilly, C. A., \& Tushman, M. L. (2008). Ambidexterity as a dynamic capability: Resolving the innovator's dilemma. Research in organizational behavior, 28, 185-206.

Organisation for Economic Co-operation and Development (2005). Oslo Manual. Guidelines for Collecting and Interpreting Innovation Data (3rd ed.). Paris: OECD Publishing.

Palm, K., Lilja, J., \& Wiklund, H. (2016). The challenge of integrating innovation and quality management practice. Total Quality Management \& Business Excellence, 27(1-2), 34-47. doi:10.10 80/14783363.2014.939841

Popadiuk, S., \& Bido, D. D. S. (2016). Exploration, exploitation, and organizational coordination mechanisms. Revista de Administração Contemporânea, 20(2), 238-260. doi:10.1590/1982-7849rac2016150018

Prange, C., \& Schlegelmilch, B. B. (2016). Towards a balanced view of innovations. Management Decision, 54(2), 441-454. doi:10.1108/md-052015-0198

O'Cass, A., Heirati, N., \& Ngo, L. V. (2014). Achieving new product success via the 
synchronization of exploration and exploitation across multiple levels and functional areas. Industrial Marketing Management, 43(5), 862872. doi:10.1016/j.indmarman.2014.04.015

Piao, M., \& Zajac, E. J. (2016). How exploitation impedes and impels exploration: Theory and evidence. Strategic Management Journal, 37(7), 1431-1447. doi:10.1002/smj.2402

Raisch, S., Birkinshaw, J., Probst, G., \& Tushman, M. L. (2009). Organizational ambidexterity: Balancing exploitation and exploration for sustained performance. Organization Science, 20(4), 685-695. doi: 10.1287/orsc.1090.0428

Rothaermel, F. T., \& Deeds, D. L. (2004). Exploration and exploitation alliances in biotechnology: A system of new product development. Strategic Management Journal, 25(3), 201-221. doi: 10.1002/smj.376

Silveira-Martins, E., \& Rossetto, C. R. (2014). Ambidestria organizacional-exploração e explotação: Um estudo bibliométrico nas bases de dados internacionais. Revista Gestão Organizacional, 7(2), 15-29.

Silveira-Martins, E., Rossetto, C. R., \& Añaña, E. da S., (2014). Ambidestria, exploração ou explotação e seus efeitos no desempenho organizacional de vinícolas brasileiras. Revista em Agronegócio e Meio Ambiente, 7(3), 707-732.

Sirén, C. A., Kohtamäki, M., \& Kuckertz, A. (2012). Exploration and exploitation strategies, profit performance, and the mediating role of strategic learning: Escaping the exploitation trap. Strategic Entrepreneurship Journal, 6(1), 18-41. doi: 10.1002/sej.1126

Smith, W. K., \& Tushman, M. L. (2005). Managing strategic contradictions: A top management model for managing innovation streams. Organization Science, 16(5), 522-536. doi: $10.1287 /$ orsc. 1050.0134
Soosay, C., \& Hyland, P. (2008). Exploration and exploitation: The interplay between knowledge and continuous innovation. International Journal of Technology Management, 42(1-2), 20-35. doi: 10.1504/ijtm.2008.018058

Su, Z., Li, J., Yang, Z., \& Li, Y. (2011). Exploratory learning and exploitative learning in different organizational structures. Asia Pacific Journal of Management, 28(4), 697-714. doi: 10.1007/s10490-009-91779

Turner, N., \& Lee-Kelley, L. (2013). Unpacking the theory on ambidexterity: An illustrative case on the managerial architectures, mechanisms and dynamics. Management Learning, 44(2), 179-196. doi: $10.1177 / 1350507612444074$

Tushman, M. L., \& O’Reilly, C. A. (1996). Organizations: managing evolutionary and revolutionary change. California Management Review, 38(4), 8-30.

Tushman, M. L., \& O'Reilly., C. A. (1997). Winning Through Innovation. Harvard Business School Press, Boston, MA. doi: 10.2307/41165852

Visser, M., de, Weerd-Nederhof, P., Faems, D., Song, M., Van Looy, B., \& Visscher, K. (2010). Structural ambidexterity in NPD processes: A firm-level assessment of the impact of differentiated structures on innovation performance. Technovation, 30(5), 291-299. doi: 10.1016/j.technovation.2009.09.008

Voss, C., Tsikriktsis, N., \& Frohlich, M. (2002). Case research in operations management. International journal of operations \& production management, 22(2), 195-219. doi: $10.1108 / 01443570210414329$

Voss, G. B., \& Voss, Z. G. (2012). Strategic ambidexterity in small and medium-sized enterprises: Implementing exploration and exploitation in product and market domains. Organization Science, 24(5), 1459-1477. oi: $10.1287 /$ orsc. 1120.0790 
Wang, C. L., \& Rafiq, M. (2014). Ambidextrous organizational culture, contextual ambidexterity and new product innovation: A comparative study of UK and Chinese high-tech firms. British Journal of Management, 25(1), 58-76. doi: 10.1111/j.1467-8551.2012.00832.x

Westerman, G., McFarlan, W. F., \& Iansiti, M. (2006). Organizational design and effectiveness over the innovation life cycle. Organizational Science, 17(2), 230-238. doi: 10.1287/ orsc. 1050.0170

Xu, L., Cui, N., Qualls, W., \& Zhang, L. (2017). How socialization tactics affect supplier-buyer co-development performance in exploratory and exploitative projects: The mediating effects of cooperation and collaboration. Journal of Business Research, 78, 242-251. doi: 10.1016/j. jbusres.2016.12.019

Yang, T.-T., Y., \& Li, C. R. (2011). Competence exploration and exploitation in new product development. Management Decision, 49(9), 1444-1470.

Yin, R. K. (1994). Case Study Research: Design and Method (2nd ed.). London: Elsevier.

Zairi, M. (1995). Moving from continuous to discontinuous innovation in FMCG: a re-engineering perspective. World Class Design to Manufacture, 2(5), 32-37. doi: $10.1108 / 09642369310095201$

\section{Supporting Agencies:}

Conselho Nacional de Desenvolvimento Científico e Tecnológico-CNPq, Brazil - grant \#45994220140.

\section{About the Authors:}

1.Fabiane Letícia Lizarelli, PhD in Production Engineering, Federal University of São Carlos, São Carlos, Brazil. Email: fabiane@dep.ufscar.br

\section{ORCID}

(iD) 0000-0002-8959-9982

2. José Carlos de Toledo, PhD in Production Engineering, University of São Paulo, São Paulo, Brazil. Email: toledo@ufscar.br

ORCID

(iD) 0000-0002-7625-0984

3. Dário Henrique Alliprandini, PhD in Mechanical Engineering, University of São Paulo, São Carlos, Brazil. Email: dario.allip@gmail.com

ORCID

(iD) 0000-0001-7541-9955

\section{Contribution of each author}

\begin{tabular}{|c|c|c|c|}
\hline Contribution & $\begin{array}{c}\text { Fabiane Letícia } \\
\text { Lizarelli }\end{array}$ & $\begin{array}{c}\text { José Carlos de } \\
\text { Toledo } \\
\end{array}$ & $\begin{array}{c}\text { Dário Henrique } \\
\text { Alliprandini }\end{array}$ \\
\hline 1. Definition of research problem & $\sqrt{ }$ & $\sqrt{ }$ & \\
\hline 2. Development of hypotheses or research questions (empirical studies) & $\sqrt{ }$ & $\sqrt{ }$ & \\
\hline 3. Development of theoretical propositions (theoretical work) & $\sqrt{ }$ & $\sqrt{ }$ & \\
\hline 4. Theoretical foundation/Literature review & $\sqrt{ }$ & $\sqrt{ }$ & $\sqrt{ }$ \\
\hline 5. Definition of methodological procedures & $\sqrt{ }$ & $\sqrt{ }$ & $\sqrt{ }$ \\
\hline 6. Data collection & $\sqrt{ }$ & & \\
\hline 7. Statistical analysis & - & - & - \\
\hline 8. Analysis and interpretation of data & $\sqrt{ }$ & $\sqrt{ }$ & $\sqrt{ }$ \\
\hline 9. Critical revision of the manuscript & $\sqrt{ }$ & $\sqrt{ }$ & $\sqrt{ }$ \\
\hline 10. Manuscript writing & $\sqrt{ }$ & $\sqrt{ }$ & $\sqrt{ }$ \\
\hline
\end{tabular}

